\title{
'n Suid-Afrikaanse Vereniging vir Atmosferiese Wetenskappe
}

Vir diegene wat in hierdie aangeleentheid belangstel, is dit reeds etlike jare duidelik dat die atmosferiese wetenskappe in Suid-Afrika op die vooraand van groot uitbreidings staan. Tekenend hiervan is die Nasionale Program vir Klimaat, Weer en Atmosferiese Wetenskappe wat deur die Koöperatiewe Wetenskaplike Programme van die WNNR geloods is, en wat die afgelope paar jaar 'n steeds groeiende aantal hoogstaande aansoeke om befondsing ontvang. Simposia oor aangeleenthede rakende atmosferiese wetenskappe word ook al hoe beter bygewoon. By die mees onlangse Simposium oor Atmosferiese Wetenskappe in Suid-Afrika, wat op 19 Oktober 1983 in die WNNR se Konferensiesentrum in Pretoria plaasgevind het, was die opkoms so dat daar 'n algemene gevoel onder simposiumgangers was dat die tyd nou ryp geword het om oor te gaan tot die amptelike stigting van 'n Suid-Afrikaanse Vereniging vir Atmosferiese Wetenskappe.

'n Komitee is vervolgens gekies om die vereniging te loods. Volgens besluit van hierdie komitee is die naam van die vereniging Die Suid-Afrikaanse Vereniging vir Atmosferiese Wetenskappe (The South African Society for Atmospheric Sciences).

Die doelstellings van die vereniging is:

(1) om die belangstelling in en ondersteuning van al die vertakkings van die atmosferiese wetenskappe te stimuleer;

(2) om navorsing en opleiding in die atmosferiese wetenskappe aan te moedig; en
(3) om samewerking tussen organisasies en inrigtings wat in die atmosferiese wetenskappe belang het, te bevorder.

Onder atmosferiese wetenskappe word alle vakgebiede ingesluit wat direk of minder direk met die atmosfeer skakel. Weer, klimaat, lugbesoedeling, wolkfisika, ens. ressorteer meer spesifiek onder die eerste kategorie, terwyl bolugfisika, fisiese geografie en fisiese oseanologie meer indirek met die atmosfeer skakel maar nogtans ingesluit is in die vereniging se doelstellings.

As eerste mikpunt om die doelstellings te verwesenlik, stel die vereniging hom ten doel om ten minste een maal per jaar 'n volskaalse simposium te reël. Kleiner streeksbyeenkomste, kort opleidingskursusse en uitstappies word ook voorsien, terwyl 'n omsendbrief aan lede alreeds die lig gesien het.

Die vereniging se opnemingsbyeenkoms word vir Vrydag, 26 Oktober 1984, in die WNNR-Konferensiesentrum beplan, om saam te val met die Internasionale Lugbesoedelingskonferensie.

Alle persone wat in die werksaamhede van die vereniging belang stel of graag lid wil word, kan om aansoekvorms vir lidmaatskap skrywe aan die vereniging se sekretaris:

Dr. D.v.d.S. Roos

NFNL/WNNR

Posbus 395

PRETORIA 0001 